\title{
ТЕОРИЯ И ПРАКТИКА
}

ГОСУДАРСТВЕННО-ПРАВОВОГО РАЗВИТИЯ

DOI: https://doi.org/10.15688/lc.jvolsu.2018.2.12

UDC 336.22

LBC 65.26

\section{TAX CONSULTING IN THE RUSSIAN FEDERATION: THE STATE AND TRENDS}

\author{
Irina S. Zemlyanskaya \\ Volgograd Institute of Management - Branch of Russian Presidential Academy of National Economy \\ and Public Administration, Volgograd, Russian Federation
}

\begin{abstract}
Introduction: the article is devoted to the problems associated with the development of the tax consulting market in the Russian Federation, since the institution of tax consulting and tax consultants have a significant impact on the state of entrepreneurial activity of the citizens, the formation of the state budget and the overall economic development of the state. For this purpose, the author examines the structure, state and trends of the tax consulting market. Using the methods of scientific cognition, first of all, the method of system analysis, it is established that, in fact, the formation and development of tax consulting in Russia have occurred since the formation of tax service. The analysis and evaluation of the activities of tax consultants and the largest consulting groups and companies in the field of taxation in Russia are conducted. Results: it is pointed out that, despite the established practice of functioning tax consulting, today there is still no normative regulation of consulting activities and legislative consolidation of the term "tax consulting". The analysis of the number of employees of the Federal Tax Service and the number of tax consultants for the period from 2014 till 2016, as well as the determination of the adequacy of the number of tax consultants as a balance of tax inspector - tax consultant in respect of approximately 10/11, leads to the conclusion that in Russia there should be about 140,000 145,000 tax consultants. It is noted that the demand for the sphere of tax consulting is confirmed by a fairly stable demand for services in this sphere. The causes of the ambiguous dynamics of the net profit of the largest consulting groups and companies of Russia in the field of taxation for the period from 2014 till 2016 are identified. Conclusions: the adoption of Federal law on Tax Consulting will make it possible to regulate common mechanisms, standards and rules for establishing liability, regulating and developing the activities of tax consultants in Russia. It is proposed to consider as a promising direction the joint organization of work of tax consultants and the state bodies in order to discuss the topical issues of tax consulting, which will reduce the level of tax conflicts.

Key words: tax consulting, tax consultant, categories of tax consultant, Chamber of Tax Consultants of the Russian Federation, Federal Tax Service of the Russian Federation (FTS of the Russian Federation), Unified register of certified tax consultants, taxation.
\end{abstract}

УДК 336.22

$\infty$ ББК 65.26

\section{НАЛОГОВОЕ КОНСУЛЬТИРОВАНИЕ В РОССИЙСКОЙ ФЕДЕРАЦИИ: СОСТОЯНИЕ И ТЕНДЕНЦИИ РАЗВИТИЯ}

\section{Ирина Сергеевна Землянская}

Волгоградский институт управления - филиал Российской академии народного хозяйства и государственной службы при Президенте Российской Федерации, г. Волгоград, Российская Федерация 
Введение: статья посвящена выявлению проблем, связанных с развитием рынка налогового консультирования в Российской Федерации, поскольку институт налогового консультирования и деятельность налоговых консультантов оказывают существенное влияние на состояние предпринимательской активности граждан, формирование бюджета государства и в целом на экономическое развитие государства. С этой целью автор изучает структуру, состояние и тенденции развития рынка налогового консультирования. С помощью методов научного познания, прежде всего метода системного анализа, установлено, что становление и развитие налогового консультирования в России происходило фактически с момента образования налоговой службы. Проводится анализ и оценка деятельности налоговых консультантов и крупнейших консалтинговых групп и компаний России в сфере налогообложения. Результаты: указывается на то, что, несмотря на сложившуюся практику функционирования налогового консалтинга, на сегодняшний день до сих пор отсутствуют нормативное регулирование консалтинговой деятельности и законодательное закрепление термина «налоговое консультирование». Анализ численности работников ФНС России и количества налоговых консультантов за период 2014-2016 гг., а также определение достаточности количества налоговых консультантов как соотношение налоговый инспектор - налоговый консультант в отношении примерно 10/11 позволяют сделать вывод, что в России в настоящее время должно действовать примерно 140 000-145 000 налоговых консультантов. Отмечается, что востребованность сферы налогового консалтинга подтверждается достаточно стабильным спросом на услуги данной сферы. Выявлены причины неоднозначной динамики прибыли крупнейших консалтинговых групп и компаний России в сфере налогообложения за период 2014-2016 годов. Выводы: принятие Федерального закона о налоговом консультировании позволит регламентировать единые механизмы, стандарты и правила установления ответственности, регулирования и развития деятельности налоговых консультантов в России. Предлагается рассмотреть как перспективное направление совместную организацию работы налоговых консультантов и государственных органов с целью обсуждения актуальных проблем налогового консультирования, что позволит снизить уровень налоговых конфликтов.

Ключевые слова: налоговое консультирование, налоговый консультант, категории налогового консультанта, Палата налоговых консультантов РФ, Федеральная налоговая служба РФ (ФНС РФ), Единый реестр аттестованных налоговых консультантов, налогообложение.

\section{Введение}

В настоящее время одним из важнейших элементов сферы услуг являются консультационные (консалтинговые) услуги. В условиях часто меняющегося налогового законодательства к услугам налогового консультирования обращаются все больше людей и организаций, а налоговые консультанты приобретают статус важного участника налоговых отношений. Так, в общую часть Налогового кодекса Российской Федерации, действующую с 1 января 2000 г., вносились поправки более 200 раз [7]. А.В. Брызгалин, выступая 5 октября 2016 г. на научно-методическом семинаре Аналитического управления Аппарата Совета Федерации, приводит данные, что в 2014 г. в сфере налогообложения и «вообще по фискалитету (это бухгалтерский учет, налоговый учет - все, что примерно вокруг налогов связано)» было принято 555 федеральных и конституционных законов [6, с. 38].

Постоянные изменения в налоговом законодательстве определяют важную роль и значение налогового консультирования на современном этапе развития экономики. «Вме- сте с тем общественный запрос на услуги налогового консультирования возрастает в силу активного развития системы налогового администрирования, в том числе в части налогового администрирования физических лиц» [17].

\section{Становление и развитие налогового консультирования В РФ}

Несмотря на то что «налоговое консультирование начало развиваться в нашей стране где-то с 2001 г.», до сих пор не принят основной нормативно-правовой акт, регулирующий налоговое консультирование в России [23]. Отсутствует и законодательное закрепление термина «налоговое консультирование». В таблице 1 приведены определения данного термина из нескольких редакций проекта Закона «Об организации налогового консультирования в Российской Федерации» и позиция некоторых российских ученых и экономистов по его формулировке.

Ключевые мероприятия в истории формирования налогового консультирования в России представлены в таблице 2. 
Трактовка термина «налоговое консультирование»

\begin{tabular}{|c|c|}
\hline Автор & Определение термина «налоговое консультирование» \\
\hline $\begin{array}{l}\text { А.М. Макаров (автор версии } \\
\text { Федерального закона от } 2014 \text { г. } \\
\text { «Об организации налогового } \\
\text { консультирования в Россий- } \\
\text { ской Федерации») (проект } \\
\text { № 529626-6) [22] }\end{array}$ & $\begin{array}{l}\text { Деятельность, осуществляемая налоговыми консультантами или налоговыми кон- } \\
\text { сультациями по оказанию консультационных услуг в сфере отношений, регулируе- } \\
\text { мых законодательством }\end{array}$ \\
\hline $\begin{array}{l}\text { Ф.А. Гудков (автор версии Фе- } \\
\text { дерального закона от } 2007 \text { г. } \\
\text { «Об организации налогового } \\
\text { консультирования в Россий- } \\
\text { ской Федерации») [11] }\end{array}$ & $\begin{array}{l}\text { Деятельность по налоговому консультированию заключается в оказании лицам, ко- } \\
\text { торые являются плательщиками налогов и сборов, предусмотренных законодатель- } \\
\text { ством РФ, консультационных, информационных и представительских услуг по во- } \\
\text { просам исчисления, уплаты налогов и сборов, установленных законодательством РФ, } \\
\text { представления форм налоговой отчетности, а также по вопросам защиты прав и ин- } \\
\text { тересов налогоплательщиков и плательщиков сборов, определяемых законодательст- } \\
\text { вом РФ о налогах и сборах (услуг по налоговому консультированию) }\end{array}$ \\
\hline $\begin{array}{l}\text { А.И. Соломанин (автор версии } \\
\text { Федерального закона «О нало- } \\
\text { говом консультировании» от } \\
2006 \text { г.) [12] }\end{array}$ & $\begin{array}{l}\text { Деятельность по налоговому консультированию - это предпринимательская деятель- } \\
\text { ность, осуществляемая лицами, получившими статус налогового консультанта в ус- } \\
\text { тановленном законом порядке по оказанию содействия в своевременной и полной } \\
\text { уплате налогов и сборов и в обеспечении реализации законных прав и интересов } \\
\text { участников отношений, регулируемых законодательством о налогах и сборах }\end{array}$ \\
\hline Т.А. Деми & $\begin{array}{l}\text { Профессиональная помощь собственникам и (или) руководителям компаний, руко- } \\
\text { водителям бухгалтерских и финансовых подразделений, работникам (менеджерам) } \\
\text { высшего и среднего звена в виде советов и рекомендаций, направленных на решение } \\
\text { возникших проблем, связанных с налогообложением }\end{array}$ \\
\hline Е.Г. Дедкова [8] & $\begin{array}{l}\text { Услуги, оказываемые на возмездной основе, по ведению налогового учета и разра- } \\
\text { ботке не запрещенных законодательно схем налоговой оптимизации, учитывая осо- } \\
\text { бенности деятельности организации клиента }\end{array}$ \\
\hline $\begin{array}{l}\text { Д.Г. Черник, Л.С. Кирина, В.В. } \\
\text { Балакин [26] }\end{array}$ & $\begin{array}{l}\text { Способ реализации прав конкретного налогоплательщика на получение квалифици- } \\
\text { рованной помощи профессионала }\end{array}$ \\
\hline
\end{tabular}

Таблица 2

Основные даты становления и развития налогового консультирования в РФ

\begin{tabular}{|c|c|}
\hline Дата & Событие \\
\hline 4 августа 2000 г. & $\begin{array}{l}\text { Постановлением № } 57 \text { Министерство труда и социального развития РФ ввело в «Квалификаци- } \\
\text { онный справочник должностей руководителей, специалистов и других служащих» новую ква- } \\
\text { лификацию «Консультант по налогам и сборам» }\end{array}$ \\
\hline 1 сентября 2000 г. & $\begin{array}{l}\text { Пять московских вузов начали подготовку налоговых консультантов по программам, утвер- } \\
\text { жденным Министерством РФ по налогам и сборам }\end{array}$ \\
\hline 2000-2001 гг. & $\begin{array}{l}\text { Квалификационный аттестат «Консультант по налогам и сборам» получили первые } 700 \text { специа- } \\
\text { листов. Возникла необходимость создания профессионального сообщества налоговых консуль- } \\
\text { тантов }\end{array}$ \\
\hline 9 января 2002 г. & Зарегистрировано некоммерческое партнерство «Палата налоговых консультантов» \\
\hline С октября 2003 г. & $\begin{array}{l}\text { Издается журнал «Налоговые споры» - официальный печатный орган Палаты налоговых кон- } \\
\text { сультантов }\end{array}$ \\
\hline 14 декабря 2004 г. & $\begin{array}{l}\text { На Общем собрании членов Палаты утверждены «Нормы профессиональной этики налоговых } \\
\text { консультантов» }\end{array}$ \\
\hline 20 апреля 2005 г. & $\begin{array}{l}\text { Министерство юстиции РФ зарегистрировало Межрегиональную общественную организацию } \\
\text { «Палата налоговых консультантов» }\end{array}$ \\
\hline З настоя & йской конфедерации налоговых кон \\
\hline
\end{tabular}

Составлено автором по: [23].

Таким образом, история развития налогового консультирования в России началась фактически с момента образования налоговой службы. Однако, несмотря на сложившуюся практику функционирования налогового консалтинга, на сегодняшний день до сих пор отсутствует нормативное регулирование консалтинговой деятельности.

\section{Профессия}

налоговый консультант в РФ

В 2002 г. было создано профессиональное сообщество - Палата налоговых консультантов, некоммерческой организации, которая объединила на добровольной основе субъектов налогового консультирования. Ее основа- 
телями стали: РосНОУ, Институт экономики и финансов «Синергия», Московский социально-экономический институт, ГУУ и Научнометодологический центр при Министерстве по налоговым сборам.

По мнению П.Л. Алтухова и О.А. Чурбановой, «сегодня можно уверенно говорить о том, что налоговое консультирование в России оформилось как явление». Указанные авторы приводят интересные данные по количеству налоговых консультантов. Так, по состоянию на май 2014 г. Единый реестр консультантов по налогам и сборам содержал 8023 записи (для сравнения: в 2001 г. - 14 записей, в 2003 г. - 757 записей, в 2005 г. - 3221 запись) [1].

По официальным данным Палаты налоговых консультантов РФ общая численность налоговых консультантов, аттестованных с 2002 г. по 31 декабря 2015 г., составила 15238 человек [21]. В настоящее время в Едином реестре аттестованных налоговых консультантов (по состоянию на 10.112017 г.) указано всего 3735 аттестованных налоговых консультантов, действующих на территории Российской Федерации [10]. Данный реестр позволяет определить:

1) регион проживания налогового консультанта;

2) город проживания;

3) номер аттестата налогового консультанта;

4) дату выдачи аттестата налогового консультанта;

5) дату окончания действия аттестата налогового консультанта;

6) категорию специалиста.

I категория присваивается налоговому консультанту II категории, успешно прошедшему тематическое собеседование в Палате налоговых консультантов РФ, при наличии действующего свидетельства о продлении срока действия квалификационного аттестата и стажа работы в области экономики и/или права не менее 10 лет из последних 12.

II категория присваивается:

- налоговому консультанту, прошедшему обучение по программе «Налоговое консультирование» объемом 380 или 180 акад. ч и успешно сдавшему квалификационный экзамен;

- налоговому консультанту III категории в порядке, определяемом в зависимости от оснований присвоения III категории.
III категория присваивается: во-первых, налоговому консультанту, прошедшему обучение по программе «Налоговое консультирование» объемом 240 акад. ч и успешно сдавшему квалификационный экзамен; во-вторых, налоговому консультанту, не имеющему достаточного опыта работы, но прошедшему обучение по программе «Налоговое консультирование» объемом 380 акад. ч и успешно сдавшему квалификационный экзамен; в-третьих, налоговому консультанту, сдавшему квалификационный экзамен на присвоение квалификации «Консультант по налогам и сборам II категории», но набравшему по его итогам 4244 балла (ниже базового проходного балла) (действует в отношении налоговых консультантов, прошедших подготовку до 01.092017 г.).

Кроме указанных трех категорий налогового консультанта, Палатой налоговых консультантов проводится обучение:

- по программе, предназначенной для повышения квалификации специалистами, практикующими в сфере экономики и желающими получить прикладные знания в сфере налогообложения бизнеса, с выдачей сертификата «Налоговый экономист» Палаты налоговых консультантов;

- по программе, предназначенной для повышения квалификации специалистами, практикующими в сфере юриспруденции и желающими получить прикладные знания в сфере налогообложения бизнеса, с выдачей сертификата «Налоговый юрист» Палаты налоговых консультантов.

По состоянию на 10.112017 г. 94 \% налоговых консультантов имеют II категорию, все остальные категории являются менее значительными (табл. 3).

Таблица 3

Количество и доля категорий налоговых консультантов в РФ

\begin{tabular}{|c|c|c|}
\hline $\begin{array}{c}\text { Категория } \\
\text { специалиста }\end{array}$ & $\begin{array}{c}\text { Количество налого- } \\
\text { вых консультантов, } \\
\text { чел. }\end{array}$ & $\begin{array}{c}\text { Доля налоговых кон- } \\
\text { сультантов от общего } \\
\text { количества, \% }\end{array}$ \\
\hline I & 17 & 0,46 \\
\hline II & 3509 & 94,00 \\
\hline III & 175 & 4,69 \\
\hline $\begin{array}{l}\text { Налоговый } \\
\text { экономист }\end{array}$ & 8 & 0,21 \\
\hline $\begin{array}{l}\text { Налоговый } \\
\text { юрист }\end{array}$ & 26 & 0,70 \\
\hline Всего & 3735 & 100,00 \\
\hline
\end{tabular}

Составлено и рассчитано автором по: [10]. 


\section{ТЕОРИЯ И ПРАКТИКА ГОСУДАРСТВЕННО-ПРАВОВОГО РАЗВИТИЯ}

Данные Единого реестра аттестованных налоговых консультантов позволяют также проанализировать долю налоговых консультантов, получивших аттестат налогового консультанта и продолжающих свою деятельность по настоящее время. Так, 91 \% (3 390 чел.) налоговых консультантов, дата выдачи аттестата налогового консультанта которых с 2007 по 2017 г., продолжают свою деятельность и по настоящее время.

Самую низкую долю $(0,08$ \%) составляют налоговые консультанты, продолжающие свою деятельность в настоящее время, выдача аттестата которых датируется 2000 годом. Данные о количестве и доле налоговых консультантов, получивших аттестат налогового консультанта в 2001-2006 гг. и продолжающих свою деятельность по настоящее время, представлены в таблице 4.

В 2013 г. в интервью Д. Черник, отвечая на вопросы о том «Сколько сейчас в России практикующих налоговых консультантов?» и «Достаточно ли этих специалистов для квалифицированной помощи налогоплательщикам?», сказал, что «количество специалистов, которые прошли обучение (сегодня это более 12 тыс. человек), и число людей, которые работают непосредственно налоговыми консультантами, не совпадают. Последних значительно меньше» [15]. По данным на 2013 г. Д. Черник приводит интересные данные о сравнении количества налогоплательщиков в зарубежных странах и России. Так, «в Австралии на 18 млн населения приходится 18 тыс. работников Австралийского налогового управления и 21 тыс. налоговых консультантов». В России в данный период насчитывалось примерно 140 тыс. налоговых работников и 5 тыс. налоговых консультантов, реально действующих, за исключением тех, кто работал внутри компаний. Д. Черник делает в связи с этим вывод, что в России должно действовать около 155 тыс. налоговых консультантов [15].

«В таких странах, как США, Англия, Франция, Германия, Австрия, соотношение налоговый инспектор - налоговый консультант примерно 10/11. В России примерно 142 тыс. налоговых инспекторов, то есть потребность в налоговых консультантах - 155 тыс., a peально есть семь тысяч» [24].

Анализ распределения и изменения числа работников территориальных органов федеральных органов исполнительной власти свидетельствует о том, что общая численность работников ФНС России в 2008 г. по сравнению с 2005 г. выросла на $4 \%$, составив при этом в 2005 г. всего 176475 единиц, а в 2008 г. - 183596 единиц [5]. В таблице 5 представлены данные по численности работников ФНС России и доля численности работников ФНС России в общей численности работников федеральных государственных органов власти за период 2014-2016 годов.

Таблица 4

Количество налоговых консультантов, продолжающих свою деятельность по настоящее время (2000-2017 гг.)

\begin{tabular}{|l|c|c|}
\hline \multicolumn{1}{|c|}{\begin{tabular}{|c|} 
Дата выдачи аттестата \\
налогового консультанта
\end{tabular}} & $\begin{array}{c}\text { Количество налоговых кон- } \\
\text { сультантов, продолжающих } \\
\text { свою деятельность по на- } \\
\text { стоящее время (по состоя- } \\
\text { нию на 10.11 2017 г.), чел. }\end{array}$ & $\begin{array}{c}\text { Доля налоговых консультантов, про- } \\
\text { должающих свою деятельность по } \\
\text { логовых консультантов из Реестра } \\
\text { (по состоянию на 10.11 2017 г.), \% }\end{array}$ \\
\hline 2000 г. & 3 & 0,08 \\
\hline 2001 г. & 7 & 0,19 \\
\hline 2002 г. & 32 & 0,86 \\
\hline 2003 г. & 73 & 2,00 \\
\hline 2004 г. & 72 & 1,90 \\
\hline 2005 г. & 113 & 3,00 \\
\hline 2006 г. & 3390 \\
\hline $\begin{array}{l}\text { Всего налоговых консультантов, по- } \\
\text { лучивших аттестат с 2007 по 2017 г. } \\
\text { (по состоянию на } 10.112017 \text { г.), из } \\
\text { числа зарегистрированных в Реестре }\end{array}$ & & 91,00 \\
\hline $\begin{array}{l}\text { Всего налоговых консультантов (по } \\
\text { состоянию на 10.11 2017 г.) }\end{array}$ & 335 & 100,00 \\
\hline
\end{tabular}

Составлено и рассчитано автором по: [10]. 
И.С. Землянская. Налоговое консультирование в Российской Федерации: состояние и тенденции развития

Численность работников ФНС России за период 2014-2016 гг.

Таблийа 5

\begin{tabular}{|c|c|c|c|}
\hline Годы & $\begin{array}{c}\text { Всего численность работников } \\
\text { федеральных государственных } \\
\text { органов, единиц }\end{array}$ & $\begin{array}{c}\text { Численность } \\
\text { работников ФНС } \\
\text { России, единиц }\end{array}$ & $\begin{array}{c}\text { Доля численности } \\
\text { работников ФНС } \\
\text { России, \% }\end{array}$ \\
\hline 2014 & 790124 & 155883 & 19,7 \\
\hline 2015 & 768037 & 155883 & 20,3 \\
\hline 2016 & 680890 & 150175 & 22,0 \\
\hline
\end{tabular}

Составлено автором по: [2-4].

Динамика численности работников ФНС России за период 2005-2016 гг. неоднозначна, поскольку за указанный период было как увеличение, так и сокращение штата работников. За период 2014-2016 гг. можно констатировать снижение численности работников ФНС России в 2016 г. по отношению к 2014 г. на $3,7 \%$. Как было отмечено выше, в Едином реестре аттестованных налоговых консультантов (по состоянию на 10.112017 г.) указано 3735 аттестованных налоговых консультантов, действующих на территории Российской Федерации. Таким образом, если исходить из зарубежной практики определения достаточности количества налоговых консультантов как соотношение налоговый инспектор - налоговый консультант в отношении примерно 10/11, то в России, исходя из приведенных данных о численности работников ФНС России выше, можно явно судить о их недостаточности.

На сайте поиска работы «Trud.com» представлен обзор статистики зарплат профессии «налоговый консультант» в Российской Федерации. В России, согласно данным указанного сайта, наибольшее количество вакансий профессии «налоговый консультант» открыто в Московской области $(37,1 \%)$. На втором месте - Ленинградская область (8,7 \%), на третьем - Республика Татарстан $(3,5 \%)$, на четвертом - Свердловская область (3,1\%), на пятом - Воронежская область и Краснодарский край (3 \%). Далее по убыванию следуют Ростовская область (2,8 \%), Новосибирская область (2,6\%), Самарская область $(2,4 \%)$. Во всех остальных субъектах РФ количество вакансий незначительное и в целом составляет $33,8 \%$.

По статистике сайта поиска работы «Trud.com» профессия налоговый консультант является наиболее высокооплачиваемой в Республике Татарстан, где уровень средней заработной платы составляет 100000 рублей.
Затем следуют Московская и Челябинская области [20]. Таким образом, помимо таких проблем в сфере развития налогового консультирования, как отсутствие законодательного регулирования, недостаток высококвалифицированных кадров, слабая конкуренция на рынке налогового консалтинга, проблема высокой стоимости услуг консультантов по вопросам налогообложения является также весьма актуальной.

\section{Анализ рынка \\ крупнейших консалтинговых групп и компаний РФ за период 2014-2016 гг.}

Ежегодно рейтинговое агентство «Эксперт РА» представляет «Обзор рынка крупнейших консалтинговых групп и компаний России», в котором приводится список крупнейших консалтинговых групп и компаний, структура выручки участников рэнкинга, темпы роста выручки участников рэнкинга по видам услуг. Кроме того, данное исследование содержит мнение и позицию ведущих специалистов в сфере ИТ-консалтинга, налогового и юридического консалтинга, финансового консалтинга и оценки, консалтинга по производству товаров и услуг, стратегического планирования и консалтинга в области маркетинга. Приведем данные анализа рынка услуг налогового и юридического консалтинга рейтингового агентства «Эксперт РА» за период 2014-2016 годов. В 2014 г. сегмент услуг налогового и юридического консалтинга был весьма емким, так как суммарно на их долю пришлось 14 \% (13,4 млрд рублей от общего дохода участников рэнкинга, где 7,4 млрд рублей - выручка в сегменте налогового консалтинга, 6 млрд рублей - выручка в сегменте юридического консалтинга). Сегменты показали прирост в 2 и $15 \%$ соответственно [27]. 


\section{ТЕОРИЯ И ПРАКТИКА ГОСУДАРСТВЕННО-ПРАВОВОГО РАЗВИТИЯ}

Суммарная выручка от услуг налогового и юридического консалтинга в 2015 г. составила 13,2 млрд рублей, из которых на сектор налоговых консультаций приходится 7,39 млрд рублей, а на юридические консультации - 5,85 млрд рублей. Прирост к прошлому рэнкингу за 2014 г. по сопоставимым данным - 0 и $5 \%$ соответственно [18]. Суммарный оборот по сектору юридических услуг составил в 2016 г. 3,69 млрд рублей (прирост $26 \%$ ). На сектор налогового консалтинга приходится 2,77 млрд руб. [19].

Выручка крупнейших консалтинговых групп и компаний России за 2014-2016 гг. представлена в таблице 6.

Проанализировав выручку крупнейших консалтинговых групп и компаний России по итогам 2014-2016 гг., мы получаем неоднозначную динамику прибыли участников рынка налогового консультирования за период 2014-2015 гг., при этом наблюдается снижение прибыли практически у большинства представленных в таблице 6 компаний в 2016 году. Таким образом, можно предположить, что на налоговый консалтинг за анализируемый период оказали влияние ряд факторов. В 2014 г. на увеличение спроса на услуги налоговых и юридических консультантов (правовые заключения, разработка методик и документов, налоговое планирование и аудит и т. д.) оказали в основном влияние деофшоризация и ужесточение налогового администрирования.

В 2015 г. увеличение спроса на налоговое консультирование сопряжено с помощью вопросов трансфертного ценообразования и контролируемых иностранных компаний, условий применения правил «тонкой капитализации», операций российских компаний с офшорными и «квазиофшорными» юрисдикциями.

В 2016 г. небольшую динамику сектора юридических услуг, в том числе налогового консалтинга, обеспечило оспаривание кадастровой стоимости, обусловленное желанием собственников и арендаторов недвижимости снизить сумму имущественных налогов. Снижение суммарных доходов участников рынка крупнейших консалтинговых групп и компаний России по итогам 2016 г. на 8 \% связано, по мнению экспертов, с обещаниями государством стабилизации в сфере налогообложения и улучшением администрирования.

\section{Выводы}

Проведенное исследование позволяет автору сделать ряд следующих выводов и предложить направления по решению проблем, существующих в настоящее время в налоговом консультировании. Во-первых, как уже

Таблица 6

Выручка крупнейших консалтинговых групп и компаний России по итогам 2014-2016 гг.

\begin{tabular}{|c|c|c|c|c|c|c|}
\hline № & $\begin{array}{c}\text { Группа } \\
\text { компаний/компания }\end{array}$ & $\begin{array}{c}\text { Выручка } \\
\text { за } 2014 \text { г., } \\
\text { тыс. руб. }\end{array}$ & $\begin{array}{c}\text { Выручка } \\
\text { за } 2015 \text { г., } \\
\text { тыс. руб. }\end{array}$ & $\begin{array}{c}\text { Темп при- } \\
\text { роста } \\
\text { в } 2015 \text { г. } \\
\text { к } 2014 \text { г., \% }\end{array}$ & $\begin{array}{c}\text { Выручка } \\
\text { за } 2016 \text { г., } \\
\text { тыс. руб. }\end{array}$ & $\begin{array}{c}\text { Темп при- } \\
\text { роста } \\
\text { в } 2016 \text { г. } \\
\text { к } 2015 \text { г., \% } \\
\end{array}$ \\
\hline 1 & $\begin{array}{l}\text { «Объединенные консультанты } \\
\text { ФДП» }\end{array}$ & 657578 & 576273 & $-12,40$ & 396709 & $-31,2$ \\
\hline 2 & «Уральский союз» & 345057 & 357444 & 3,60 & 364830 & 2,1 \\
\hline 3 & $\begin{array}{l}\text { «Юридическая Компания «Ва- } \\
\text { сильев, Солянко и партнеры» }\end{array}$ & 124970 & 97331 & $-22,10$ & 151682 & 55,8 \\
\hline 4 & $\begin{array}{l}\text { «Альянс Консалтинг Инвест- } \\
\text { мент Групп» }\end{array}$ & 180740 & 184490 & 2,07 & 103443 & $-43,9$ \\
\hline 5 & «Что делать Консалт» & 99089 & 114442 & 15,50 & 76452 & $-33,2$ \\
\hline 6 & «Налоги и финансовое право» & 74812 & 77423 & 3,50 & 74818 & $-3,4$ \\
\hline 7 & «Нексиа Си Ай Эс» & 103815 & 112569 & 8,40 & 63480 & $-43,6$ \\
\hline 8 & «Критериум» & 52016 & 52536 & 1,00 & 57036 & 8,6 \\
\hline 9 & $\begin{array}{l}\text { «онсультационное бюро } \\
\text { Дмитрия Михайлова» }\end{array}$ & 41524 & 52647 & 26,80 & 51561 & $-2,1$ \\
\hline 10 & «Эккона UHY» & 42337 & 54481 & 28,70 & 49205 & $-9,7$ \\
\hline 11 & КСК групп & 591264 & 649665 & 9,90 & 46626 & $-92,8$ \\
\hline 12 & Холдинг «Люди дела» & 33515 & 37536 & 12,00 & 42791 & 14,0 \\
\hline
\end{tabular}

Составлено и рассчитано автором по: [14]. 
указывалось в наших ранних работах, мы концептуально поддерживаем введение и применение упорядоченного налогового консультирования, которое, на наш взгляд, повысит уровень предоставления услуг в данной сфере консалтинга [13, с. 97]. Анализ выручки крупнейших консалтинговых групп и компаний России по итогам 2014-2016 гг. свидетельствует о достаточно стабильном характере спроса на услуги налогового консалтинга и, несмотря на снижение в отдельные периоды под воздействием усиления административного давления, активизации мероприятий налогового контроля, а также вследствие сложной экономической ситуации доказывает востребованность данной сферы консалтинга. В связи с этим принятие Федерального закона о налоговом консультировании позволит регламентировать единые механизмы, стандарты и правила установления ответственности, регулирования и развития деятельности налоговых консультантов в России.

Во-вторых, анализ численности работников ФНС России и количества налоговых консультантов за период 2014-2016 гг., а также определение достаточности количества налоговых консультантов как соотношения налоговый инспектор - налоговый консультант в отношении примерно 10/11 позволяют сделать вывод, что в России должно действовать примерно 140 000-145 000 налоговых консультантов.

B-третьих, в рамках развития института налогового консультирования в России перспективным представляется совместная организация работы налоговых консультантов и государственных органов с целью обсуждения актуальных проблем налогового консультирования. Информационно-консультационная поддержка налогоплательщиков как со стороны органов государственной власти, так и налоговых консультантов оказывает существенное воздействие на качество налоговых отношений, снижая уровень налоговых конфликтов. Так, М. Мишустин, подводя итоги работы налоговых органов за 2017 г., отметил, что в настоящее время основной акцент ФНС России делает на побуждение налогоплательщиков к созданию прозрачной налоговой среды и добровольному уточнению налоговых обязательств. Кроме того, он заявил, что «тренд на снижение жалоб бизнеса по результатам выездных проверок продолжается - в 2017 г. их количество снизилось на $11 \%$, а за 5 лет более чем на $32 \%$ (с 10,2 до 7 тысяч). Количество жалоб в 2017 г. по сравнению с 2013 г. снизилось почти в 5 раз (с 53 до 11 тысяч), в том числе в 2017 г. - более чем на $9 \%$ \% [25].

17 февраля 2017 г. в Институте налогового менеджмента и экономики недвижимости НИУ «Высшая школа экономики» состоялся круглый стол на тему «Налоговый консалтинг в современных условиях налогового администрирования. Проблемы и перспективы развития». В рамках данного мероприятия заместитель руководителя ФНС России Д.Ю. Григоренко в своем докладе особое внимание уделил вопросу роли налогового консалтинга в конструктивном взаимодействии с налогоплательщиками [16]. Таким образом, можно говорить о наметившихся тенденциях в России по организации совместной работы налоговых консультантов и государственных органов.

\section{СПИСОК ЛИТЕРАТУРЫ}

1. Алтухов, П. Л. Основные направления налогового консультирования в Российской Федерации / П. Л. Алтухов, О. А. Чурбанова // Налоги. 2015. - № 3. - C. 45-48.

2. Анализ расходов и численности работников федеральных государственных органов, государственных органов субъектов Российской Федерации и органов местного самоуправления на основе данных формы 14 и формы 14 MO за 20132014 годы (без Минобороны России, МВД России ФСТЭК России, СВР России, ФСБ России, ГУСП, загранаппарата федеральных государственных органов). - Электрон. текстовые дан. - Режим доступа: http://minfin.ru (дата обращения: 10.02.2018). Загл. с экрана.

3. Анализ расходов и численности работников федеральных государственных органов, государственных органов субъектов Российской Федерации и органов местного самоуправления на основе данных формы 14 и формы 14 МО за 2015 год (без Минобороны России, МВД России ФСТЭК России, СВР России, ФСБ России, ГУСП, загранаппарата федеральных государственных органов). - Электрон. текстовые дан. - Режим доступа: http://minfin.ru (дата обращения: 10.02.2018). - Загл. с экрана.

4. Анализ расходов и численности работников федеральных государственных органов, государственных органов субъектов Российской Федерации 
и органов местного самоуправления на основе данных формы 14 и формы 14 МО за 2016 год (без Минобороны России, МВД России ФСТЭК России, СВР России, ФСБ России, ГУСП, загранаппарата федеральных государственных органов. - Электрон. текстовые дан. - Режим доступа: http://minfin.ru (дата обращения: 10.02.2018). - Загл. с экрана.

5. Аналитический обзор Счетной палаты Российской Федерации по результатам экспертно-аналитического мероприятия «Анализ эффективности использования государственных средств территориальными структурами федеральных органов исполнительной власти и региональными органами исполнительной власти, выделяемых на реализацию функций управления». - Электрон. текстовые дан. - Режим доступа: http://audit.gov.ru (дата обращения: 12.01.2018). - Загл. с экрана.

6. Брызгалин, А. В. Баланс частных и публичных интересов как залог повышения эффективности налоговой системы / А. В. Брызгалин // Аналитический вестник. -2016. - № 51 (650). - С. 37-44.

7. Горовцова, М. Налоговое консультирование: новая эпоха? / М. Горовцова. - Электрон. текстовые дан. - Режим доступа: http://garant.ru (дата обращения: 12.01.2018). - Загл. с экрана.

8. Дедкова, Е. Г. Место и роль налогового консультирования в современной экономике / Е. Г. Дедкова // Экономические и гуманитарные науки. 2011. - № 7. - С. 92-99.

9. Демишева, Т. А. Организация и методика налогового консультирования / Т. А. Демишева. М. : МФЦ, 2007. - 160 с.

10. Единый реестр аттестованных налоговых консультантов (по состоянию на 10 ноября 2017 г.). Электрон. текстовые дан. - Режим доступа: http:// base.garant.ru (дата обращения: 12.01.2018). - Загл. с экрана.

11. Законопроект, авторское мнение Ф.А. Гудкова. - Электрон. текстовые дан. - Режим доступа: http://palata-nk.ru (дата обращения: 15.03.2018).Загл. с экрана.

12. Законопроект, авторское мнение А.И. Соломанина. - Электрон. текстовые дан. - Режим доступа: http://palata-nk.ru (дата обращения: 15.03.2018). Загл. с экрана.

13. Землянская, И. С. К вопросу о проекте Федерального закона № 529626-6 «О налоговом консультировании» / И. С. Землянская // Образование в XXI веке: путь к новым кризисам? : материалы II Междунар. науч.-практ. конф. (17 июня 2014 г.) : в 2 ч. Ч. 1 / отв. ред. А. Н. Плотников. - Саратов : Изд-во ЦПМ «Академия бизнеса», 2014. - С. 97-98.

14. Исследование рынка крупнейших консалтинговых групп и компаний России по итогам 2014 2016 гг. рейтингового агентства «Эксперт РА». Электрон. текстовые дан. - Режим доступа: http:// raexpert.ru (дата обращения: 25.02.2018). - Загл. с экрана.

15. Колодина, И. Все решат за вас / И. Колодина // Российская бизнес-газета: Налоговое обозрение. 2013. - № 897 (19). - Электрон. текстовые дан. - Режим доступа: http://rg.ru/2013/05/21/nalogi.html (дата обращения: 15.03.2018). - Загл. с экрана.

16. Круглый стол по теме: «Налоговый консалтинг в современных условиях налогового администрирования. Проблемы и перспективы развития». - Электрон. текстовые дан. - Режим доступа: http://re.hse.ru (дата обращения: 02.03.2018). Загл. с экрана.

17. Об Ассоциации налоговых консультантов. - Электрон. текстовые дан. - Режим доступа: http://nalog-ank.ru (дата обращения: 26.02.2018). Загл. с экрана.

18. Обзор рынка крупнейших консалтинговых групп и компаний России по итогам 2015 года. - Электрон. текстовые дан. - Режим доступа: http://raexpert.ru (дата обращения: 25.02.2018). - Загл. с экрана.

19. Обзор рынка крупнейших консалтинговых групп и компаний России по итогам 2016 года: советники держат оборону. - Электрон. текстовые дан. - Режим доступа: http://raexpert.ru (дата обращения: 25.02.2018). - Загл. с экрана.

20. Обзор статистики зарплат профессии налоговый консультант в России. - Электрон. текстовые дан. - Режим доступа: http://russia.trud.com/salary/692/ 6775 (дата обращения: 10.02.2018). - Загл. с экрана.

21. Общее собрание членов Палаты налоговых консультантов. - Электрон. текстовые дан. Режим доступа: http://palata-nk.ru (дата обращения: 15.03.2018). - Загл. с экрана.

22. Проект Федерального закона № 529626-6 «Об организации налогового консультирования в Российской Федерации» (ред., внесенная в ГД ФС РФ, текст по состоянию на 23.052014 г.). - Электрон. текстовые дан. - Режим доступа: http:/consultant.ru (дата обращения: 15.03.2018). - Загл. с экрана.

23. Профессия Налоговый консультант: описание, где учиться, необходимые качества. - Электрон. текстовые дан. - Режим доступа: http://profguide.ru (дата обращения: 18.01.2018). - Загл. с экрана.

24. России нужно 150 тыс. налоговых консультантов). - Электрон. текстовые дан. - Режим доступа: http://rosnou.ru/important/palata_nalog/ (дата обращения: 15.03.2018). - Загл. с экрана.

25. Руководитель ФНС России Михаил Мишустин подвел итоги работы налоговых органов за 2017 год. - Электрон. текстовые дан. - Режим доступа: http://nalog.ru (дата обращения: 08.02.2018). Загл. с экрана.

26. Черник, Д. Г. Налоговое консультирование : учеб. пособие / Д. Г. Черник, Л. С. Кирина, В. В. Балакин. - М. : Экономика, 2009. - 439 с. 
27. «Эксперт РА»: спад на рынке консультаций в 2014 году не зафиксирован. - Электрон. текстовые дан. - Режим доступа: http://audit-it.ru/news/ audit/830106.html (дата обращения: 25.02.2018). Загл. с экрана.

\section{REFERENCES}

1. Altukhov P.L., Churbanova O.A. Osnovnye napravleniya nalogovogo konsultirovaniya $\mathrm{V}$ Rossiyskoy Federatsii [The Main Directions of Tax Consulting in the Russian Federation]. Nalogi, 2015, no. 3, pp. $45-48$

2. Analiz raskhodov $i$ chislennosti rabotnikov federalnykh gosudarstvennykh organov, gosudarstvennykh organov subyektov Rossiyskoy Federatsii i organov mestnogo samoupravleniya na osnove dannykh formy 14 i formy 14 MO za 20132014 gody (bez Minoborony Rossii, MVD Rossii FSTEK Rossii, SVR Rossii, FSB Rossii, GUSP, zagranapparata federalnykh gosudarstvennykh organov) [Analysis of the Costs and Number of Employees of Federal State Bodies, State Bodies of the Subjects of the Russian Federation and Local Authorities on the Basis of the Data of Form 14 and Form 14 of the MO for 2013-2014 (not Taking into Account the Ministry of Defense of Russia, the Ministry of Interior of Russia, the FSTEC of Russia, the SVR of Russia, the FIS of Russia, GUSP, the State Apparatus of Federal State Bodies)]. URL: http:// minfin.ru. (accessed 10 February 2018).

3. Analiz raskhodov $i$ chislennosti rabotnikov federalnykh gosudarstvennykh organov, gosudarstvennykh organov subyektov Rossiyskoy Federatsii i organov mestnogo samoupravleniya na osnove dannyk formy 14 i formy 14 MO za 2015 god (bez Minoborony Rossii, MVD Rossii FSTEK Rossii, SVR Rossii, FSB Rossii, GUSP, zagranapparata federalnykh gosudarstvennykh organov) [Analysis of the Costs and Number of Employees of Federal State Bodies, State Bodies of the Subjects of the Russian Federation and Local Authorities on the Basis of the Data of Form 14 and Form 14 of the MO for 2015 (not Taking into Account the Ministry of Defense of Russia, the Ministry of Interior of Russia, the FSTEC of Russia, the SVR of Russia, the FIS of Russia, GUSP, the State Apparatus of Federal State Bodies)]. URL: http://minfin.ru (accessed 10 February 2018).

4. Analiz raskhodov $i$ chislennosti rabotnikov federalnykh gosudarstvennykh organov, gosudarstvennykh organov subyektov Rossiyskoy Federatsii $i$ organov mestnogo samoupravleniya na osnove dannykh formy 14 i formy 14 MO za 2016 god (bez Minoborony Rossii, MVD Rossii FSTEK Rossii, SVR Rossii, FSB Rossii, GUSP, zagranapparata federalnykh gosudarstvennykh organov) [Analysis of the Costs and Number of Employees of Federal State Bodies, State Bodies of the Subjects of the Russian Federation and Local Authorities on the Basis of the Data of Form 14 and Form 14 of the MO for 2016 (not Taking into Account the Ministry of Defense of Russia, the Ministry of Interior of Russia, the FSTEC of Russia, the SVR of Russia, the FIS of Russia, GUSP, the State Apparatus of Federal State Bodies)]. URL: http://minfin.ru (accessed 10 February 2018).

5. Analiticheskiy obzor Schetnoy palaty Rossiyskoy Federatsii po rezultatam ekspertnoanaliticheskogo meropriyatiya "Analiz effektivnosti ispolzovaniya gosudarstvennykh sredstv territorialnymi strukturami federalnykh organov ispolnitelnoy vlasti $i$ regionalnymi organami ispolnitelnoy vlasti, vydelyaemykh na realizatsiyu funktsiy upravleniya» [Analytical Review of the Accounts Chamber of the Russian Federation Based on the Results of an ExpertAnalytical Event 'Analysis of the Effectiveness of Public Funds Use by Territorial Units of Federal Executive Bodies and Regional Executive Bodies, Allocated for the Implementation of Management Functions']. URL: http:// audit.gov.ru (accessed 12 January 2018).

6. Bryzgalin A.V. Balans chastnykh i publichnykh interesov kak zalog povysheniya effektivnosti nalogovoy sistemy [The Balance of Private and Public Interests as a Pledge to Improve the Efficiency of Tax System]. Analiticheskiy vestnik, 2016, no. 51 (650), pp. 37-44.

7. Gorovtsova M. Nalogovoe konsultirovanie: novaya epokha? [Tax Consulting: a New Era?]. URL: http://garant.ru (accessed 12 January 2018).

8. Dedkova E.G. Mesto i rol nalogovogo konsultirovaniya $\mathrm{v}$ sovremennoy ekonomike [Place and Role of Tax Consulting in the Modern Economy]. Ekonomicheskie i gumanitarnye nauki, 2011, no. 7, pp. 92-99.

9. Demisheva T.A. Organizatsiya i metodika nalogovogo konsultirovaniya [Organization and Techniques of Tax Consulting]. Moscow, MFTS Publ., 2007. 160 p.

10. Edinyy reestr attestovannykh nalogovykh konsultantov (po sostoyaniyu na 10 noyabrya 2017 g.) [A Unified Register of Certified Tax Advisers (as of November 10, 2017)]. URL: http://base.garant.ru (accessed 12 January 2018).

11. Zakonoproekt, avtorskoe mnenie F.A. Gudkova [The Bill, F.A. Gudkov's Opinion]. URL: http://palata-nk.ru (accessed 15 March 2018).

12. Zakonoproekt, avtorskoe mnenie A.I. Solomanina [The Bill, A.I. Solomanin's Opinion]. URL: http://palata-nk.ru (accessed 15 March 2018).

13. Zemlyanskaya I.S. K voprosu o proekte Federalnogo zakona № 529626-6 «O nalogovom konsultirovanii» [On the Draft Federal Law No. 529626- 
6 'On Tax Consulting']. Plotnikov A.N., ed. Obrazovanie $v$ XXI veke: put $k$ novym krizisam? Materialy II Mezhdunar. nauch.-prakt. konf. (17 iyunya 2014 g.): $v 2 \mathrm{ch}$. Ch. 1 [Education in the $21^{\text {st }}$ Century: a Path to New Crises? Proceedings of the $2^{\text {nd }}$ International Research and Practice Conference (June 17, 2014). In 2 Parts. Part 1]. Saratov, Izd-vo TSPM «Akademiya biznesa», 2014, pp. 97-98.

14. Issledovanie rynka krupneyshikh konsaltingovykh grupp i kompaniy Rossii po itogam 2014-2016 gg. reytingovogo agentstva «Ekspert $R A »$ [The Research into the Market of the Largest Consulting Groups and Companies of Russia in 20142016. Expert RA Rating Agency]. URL: http:// raexpert.ru. (accessed 25 February 2018).

15. Kolodina I. Vse reshat za vas [All the Decisions Will Be Made for You]. Rossiyskaya biznes-gazeta: Nalogovoe obozrenie, 2013, no. 897 (19). URL: http:// rg.ru/2013/05/21/nalogi.html (accessed 15 March 2018).

16. Kruglyy stol po teme: "Nalogovyy konsalting $v$ sovremennykh usloviyakh nalogovogo administrirovaniya. Problemy i perspektivy razvitiya» [Round Table on the Topic 'Tax Consulting in the Modern Conditions of Tax Administration. Problems and Prospects of Development']. URL: http://re.hse.ru (accessed 2 March 2018).

17. Ob Assotsiatsii nalogovykh konsultantov [About the Association of Tax Consultants]. URL: http://nalog-ank.ru (accessed 26 February 2018).

18. Obzor rynka krupneyshikh konsaltingovykh grupp i kompaniy Rossii po itogam 2015 goda [The Research into the Market of the Largest Consulting Groups and Companies of Russia According to the Results of 2015]. URL: http://raexpert.ru (accessed 25 February 2018).

19. Obzor rynka krupneyshikh konsaltingovykh grupp i kompaniy Rossii po itogam 2016 goda: sovetniki derzhat oboronu [The Research into the Market of the Largest Consulting Groups and Companies of Russia According to the Results of 2016:
Consultants Hold the Fort]. URL: http://raexpert.ru (accessed 25 February 2018).

20. Obzor statistiki zarplat professii nalogovyy konsultant $v$ Rossii [Review of Statistics of Tax Consultants' Salaries in Russia]. URL: http://russia. trud.com/salary/692/6775 (accessed 10 February 2018).

21. Obshchee sobranie chlenov Palaty nalogovykh konsultantov [General Meeting of the Members of the Chamber of Tax Consultants]. URL: http://palata-nk.ru (accessed 15 March 2018).

22. Proekt Federalnogo zakona № 529626-6 «Ob organizacii nalogovogo konsultirovaniya $v$ Rossijskoy Federacii» (red., vnesennaya v GD FS RF, tekst po sostoyaniyu na 23.052014 g.) [Draft Federal Law No. 529626-6 ‘On Tax Consulting' (as amended by the State Duma of the Federal Assembly of the Russian Federation, as of May 23, 2014)]. URL: http:/ /consultant.ru (accessed 15 March 2018).

23. Professiya Nalogovyy konsultant: opisanie, gde uchitsya, neobkhodimye kachestva [Profession Tax Consultant: General Information, Educational Institutions and Necessary Qualities]. URL: http:// profguide.ru (accessed 18 January 2018).

24. Rossii nuzhno 150 tys. nalogovykh konsultantov [Russia Needs 150 Thousand Tax Advisers]. URL: http://rosnou.ru/important/ palata_nalog/ (accessed 15 March 2018).

25. Rukovoditel FNS Rossii Mikhail Mishustin podvel itogi raboty nalogovykh organov za 2017 god [Head of the Federal Tax Service of Russia Mikhail Mishustin Summed up the Activity of Tax Authorities for 2017]. URL: http://nalog.ru (accessed 8 February 2018).

26. ChernikD.G., Kirina L.S., Balakin V.V.Nalogovoe konsultirovanie: ucheb. posobie [Tax Consulting: Textbook]. Moscow, Ekonomika Publ., 2009. 439 p.

27. «Ekspert $R A »:$ spad na rynke konsultatsiy $v$ 2014 godu ne zafiksirovan [Expert RA Rating Agency: the Recession in the Consulting Market in 2014 Was not Fixed]. URL: http://audit-it.ru/news/audit/ 830106.html (accessed 25 February 2018).

\section{Information about the Author}

Irina S. Zemlyanskaya, Candidate of Sciences (Economics), Associate Professor, Department of Accounting, Analysis and Audit, Volgograd Institute of Management - Branch of Russian Presidential Academy of National Economy and Public Administration, Gagarina St., 8, 400131 Volgograd, Russian Federation, zemlyanskaya-irina@yandex.ru.

\section{Информация об авторе}

Ирина Сергеевна Землянская, кандидат экономических наук, доцент кафедры учета, анализа и аудита, Волгоградский институт управления - филиал Российской академии народного хозяйства и государственной службы при Президенте Российской Федерации», ул. Гагарина, 8, 400131 г. Волгоград, Российская Федерация, zemlyanskaya-irina@yandex.ru. 